\title{
Lhermitte-Duclos disease
}

\section{Sugata Narayan Biswas, Partha Pratim Chakraborty, Shinjan Patra}

Department of Medicine, Midnapore Medical College, Midnapore, West Bengal, India

\section{Correspondence to} Dr Partha Pratim Chakraborty, docparthapc@yahoo.co.in

Accepted 30 January 2016

\section{DESCRIPTION}

A 16-year-old boy presented with complaints of recent onset difficulty in walking, progressive diminution of vision and a long-standing persistent
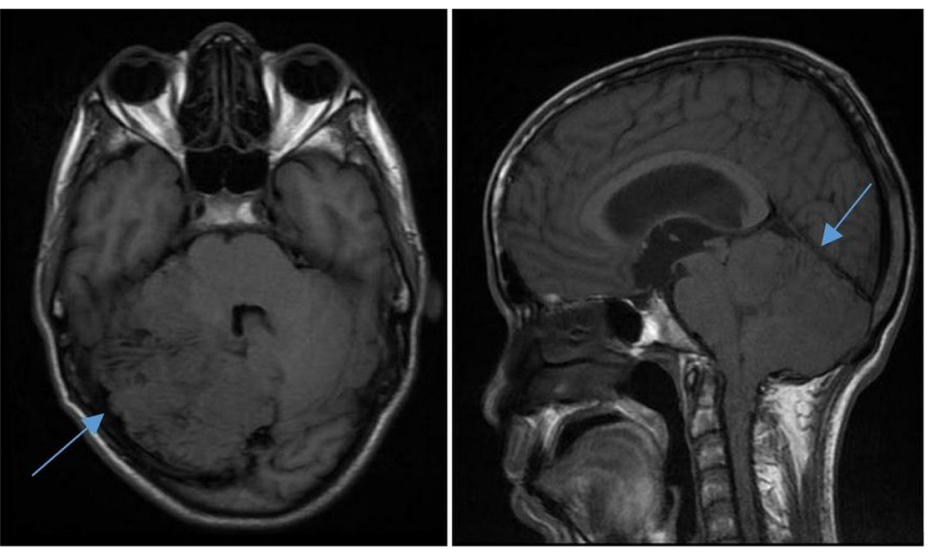

Figure 1 T1 weighted MRI of the brain showing a hypointense mass lesion (blue arrow) of right cerebellar hemisphere with striated folial pattern.
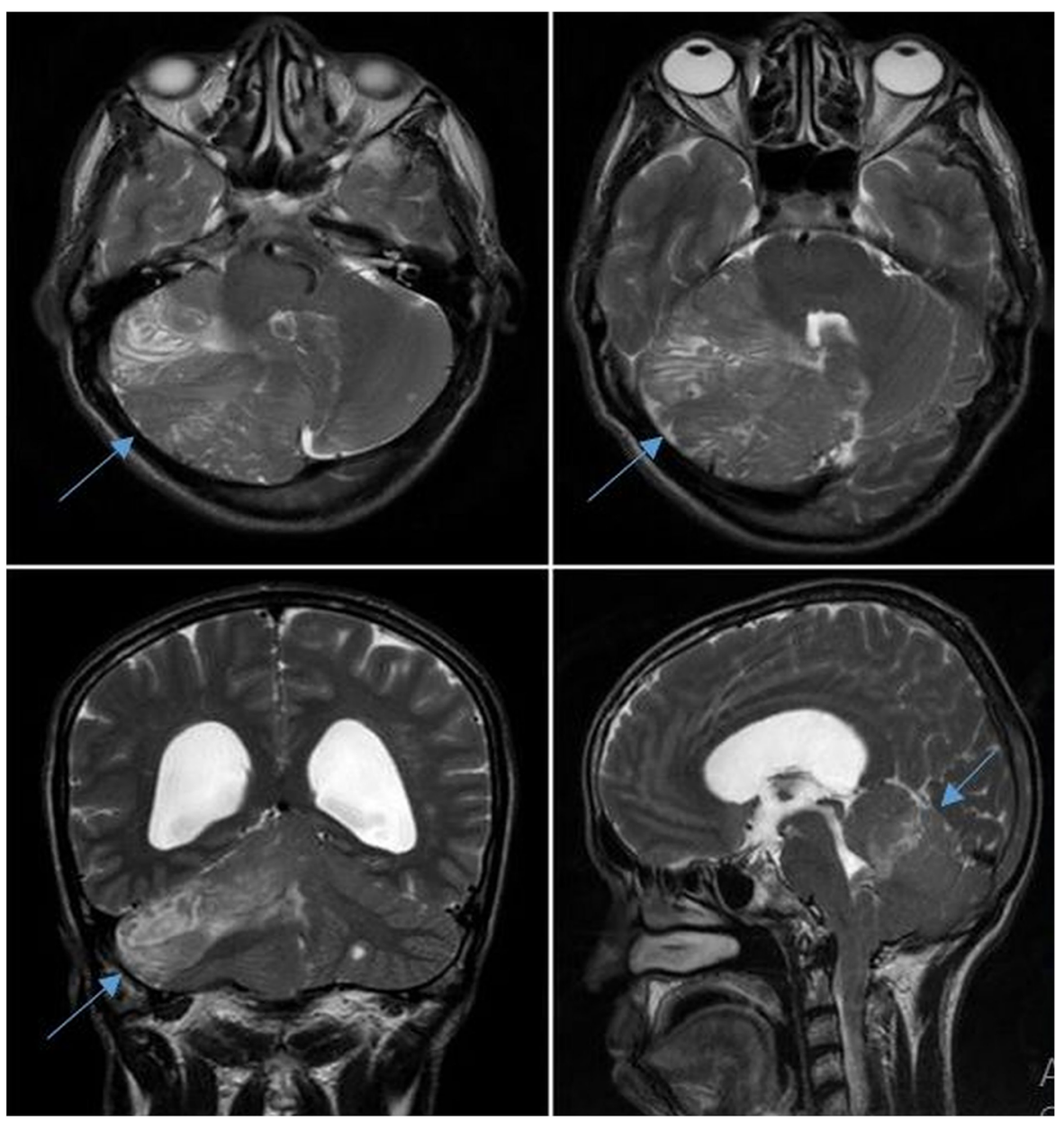

Figure 2 T2 weighted MRI of brain showing a hyperintense mass lesion (blue arrow) of right cerebellar hemisphere with striated folial pattern. occipital headache. Physical examination suggested cerebellar ataxia, positive cerebellar signs, macrocephaly and bilateral papilloedema. MRI of the brain revealed a mass lesion with prominent
To cite: Biswas $\mathrm{SN}$, Chakraborty PP, Patra S. BMJ Case Rep Published online: [please include Day Month Year] doi:10.1136/ bcr-2015-214235 
striated folial pattern involving the right cerebellar hemisphere and causing obstructive hydrocephalus. The lesion appeared hypointense on T1 (figure 1) and hyperintense on T2 (figure 2) weighted images, with parallel linear striations. A diagnosis of Lhermitte-Duclos disease was made from the classical findings on neuroimaging.

Lhermitte-Duclos disease, or dysplastic cerebellar gangliocytoma, is a rare hamartomatous lesion due to abnormal development and unilateral hemispheric expansion of the cerebellum. Although the exact aetiology remains unknown, a germline mutation of phosphatase and tensin homologue on chromosome $10 \mathrm{q} 23$ is considered widely as the underlying defect. ${ }^{1}$ Usually occurring in young adults, it manifests with headache, visual dis-

\section{Learning points}

- Lhermitte-Duclos disease, or dysplastic cerebellar gangliocytoma, is a rare hamartomatous lesion of the cerebellum, mostly occurring in young adults.

- Histological hallmarks of the disease are thickening and hypermyelination of the outer molecular layer, loss of Purkinje cells and white matter, dysplastic ganglion cells with rounded nuclei and abundant mitochondria invading the inner granular layer.

- A non-enhancing mass in posterior fossa, hypointense on T1 and hyperintense on T2-weighted images with parallel linear striations giving a 'tigroid' appearance of cerebellum, is considered diagnostic. turbances, cerebellar dysfunction, ataxia, cranial nerve palsies and occlusive hydrocephalus. ${ }^{2}$ Thickening and hypermyelination of outer molecular layer, loss of Purkinje cells and white matter, dysplastic ganglion cells with rounded nuclei and abundant mitochondria invading the inner granular layer are histological hallmarks. MRI of the brain reveals a typical striated, tigroid folial pattern of the cerebellum. ${ }^{3}$ Often, it occurs in association with Cowden disease, a multiple hamartoma-neoplasia complex. A ventriculoperitoneal shunt aimed at relieving obstructive hydrocephalus followed by resection of the mass has been planned for this patient. Knowledge of the characteristic radiological findings helps in diagnosing this rare disease and spares the need for biopsy in most cases.

Contributors SNB contributed to diagnosis of the patient, acquisition of data, concept and design of the paper, drafting of the article and final approval. PPC and SP contributed to diagnosis of the patient, concept and design of the paper, drafting of the article, intellectual input, critical revision and final approval.

Competing interests None declared.

Patient consent Obtained.

Provenance and peer review Not commissioned; externally peer reviewed.

\section{REFERENCES}

1 Zhou XP, Marsh DJ, Morrison CD, et al. Germline inactivation of PTEN and dysregulation of the phosphoinositol-3-kinase/Akt pathway cause human Lhermitte-Duclos disease in adults. Am J Hum Genet 2003;73:1191-8.

2 Milbouw G, Born JD, Martin D, et al. Clinical and radiological aspects of dysplastic gangliocytoma (Lhermitte-Duclos disease): a report of two cases with review of the literature. Neurosurgery 1988;22:124-8.

3 Meltzer CC, Smirniotopoulos JG, Jones RV. The striated cerebellum: an MR imaging sign in Lhermitte-Duclos disease (dysplastic gangliocytoma). Radiology 1995; 194:699-703.

Copyright 2016 BMJ Publishing Group. All rights reserved. For permission to reuse any of this content visit http://group.bmj.com/group/rights-licensing/permissions.

BMJ Case Report Fellows may re-use this article for personal use and teaching without any further permission.

Become a Fellow of BMJ Case Reports today and you can:

- Submit as many cases as you like

- Enjoy fast sympathetic peer review and rapid publication of accepted articles

- Access all the published articles

- Re-use any of the published material for personal use and teaching without further permission

For information on Institutional Fellowships contact consortiasales@bmjgroup.com

Visit casereports.bmj.com for more articles like this and to become a Fellow 